\title{
Group Structure and Behaviour of Babirusa (Babyrousa babyrussa) in Northern
}

\section{Sulawesi}

Maurice Patry ${ }^{1}$, Kristin Leus ${ }^{2}$ and Alastair A Macdonald ${ }^{2}$

16 Rue Christine

75006 Paris, France

2 Department of Preclinical Veterinary Sciences

The University of Edinburgh

Summerhall, Edinburgh EH9 1QH, Scotland, UK

Running head: Group structure and behaviour of babirusa

All proofs and correspondence to: Dr Alastair A Macdonald

Department of Preclinical Veterinary Sciences

The University of Edinburgh

Summerhall, Edinburgh EH9 1QH, Scotland, UK

Tel: (44) 01316506120

Fax: (44) 01316506576

e-mail: AAMacdonald@ lab0.vet.ed.ac.uk

\section{Abstract}


Studies were carried out at two 'salt-licks' in lowland tropical forest on North Sulawesi, Indonesia. During 60 days of observation 586 sightings of babirusa were made comprising 161 of adult males, 155 of adult females, 11 adults of unknown sex, 78 of subadult males, 53 of subadult females and 34 subadults of indeterminate sex; juveniles were observed 94 times, 19 males, 12 females and 63 of unknown sex. We saw 226 groups ranging in size from one to eight animals (median =2). Almost half the sightings were of solitary animals, usually adult males. Bachelor groups of four or more babirusa were never seen. Adult females were rarely seen without company, often both juveniles and subadults being sighted together with them. There were never more than three adult females in a group. There were about twice as many family groups without adult males as there were with males. Agonistic behaviour between males was confined to 'threat at a distance', 'nose in the air', 'head under jaw submission' and 'front half supported' behaviours. There were fewer incidents of femalefemale agonistic behaviour, but in two, the dominant female chased her inferior off the 'salt-lick'

\section{Introduction}

The babirusa (Babyrousa babyrussa) is a wild pig endemic to the Indonesian island of Sulawesi, some of the Togian and Sula islands, and the island of Buru (Figure 1). The available geological and fragmentary paleontological evidence indicates an early evolutionary separation from the other Suidae (Römer 1966; Audley-Charles 1981) and analysis of its karyotype concurs with this view (Bosma et al. 1991). Recent studies in the field have shown the species to be directly vulnerable to hunting, and indirectly to logging and mining pressures which are threatening its position in the wild (Smiet 1982; Blouch 1989; Oliver 1993). One consequence is that there is now an international captive breeding programme (Plasa 1994) based in zoological gardens in Asia, Europe, and North America. 
The earliest fragments of information about the behaviour of the babirusa in the wild were collected from the island of Buru by Rumphius and subsequently published by Valentijn (1726). Other comments may be found in the "hunting" reports of Guillemard (1886) and Stresemann (1925). More recently, some behavioural studies were conducted on the Togian islands by Selmier $(1978,1983)$. Despite the sum of these efforts, there is no information on the group structure of the babirusa in the wild. Studies of babirusa in zoological collections suggest that the animals may be gregarious (Macdonald et al. 1989). There is also some evidence of close bonding between the adult female and her young which may extend beyond the first year of life. Other studies of the babirusa in captivity have indicated the nature of activity patterns during the day, agonistic and marking behaviour, courtship and reproduction (Bowles 1986; Leus et al. 1992, 1995; Leus 1993, 1994; Macdonald et al. 1993). The results reported in the present paper comprise the most extensive documentation of a population of babirusa in the wild, and the first description of group sizes, group structure, agonistic and reproductive behaviour. The taxonomic nomenclature used throughout the paper is that presented in Oliver (1993).

\section{Study Area}

The study area was situated south of the Paleleh mountain range in the northern watershed draining into the Paguyaman river on the Minahasa peninsula of North Sulawesi (Sulawesi Utara) (Figure 1). The altitude was approximately $100 \mathrm{~m}$. The average annual rainfall is approximately $2000 \mathrm{~mm}$ and is slightly seasonal, the months between August and October tending to be somewhat dryer (Whitten et al. 1987). The observations were carried out at two 'salt-lick' sites about $15 \mathrm{~km}$ apart, named 'Marisa' and 'Lantolo'. The 'Marisa' site had a surface area of about $4800 \mathrm{~m}^{2}$ and was approximately rectangular in shape (Figure 2). The 'Lantolo' site was smaller and had a surface area of about 900 $\mathrm{m}^{2}$ (Figure 2). Both sites were located in dense lowland tropical forest. 
[figs $1 \& 2$ near here]

\section{Materials and Methods}

The detailed background to the videotaped observations reported in this paper have been published elsewhere (Patry 1990; Poulard and Patry 1990; Collet 1995). Observations were made from about 7.00 or 8.00 in the morning until 17.00 or 18.00 in the late afternoon between the 18 th and 19th March 1988, 2nd and 5th October 1988, 4th and 13th May 1989, 18th and 30th July 1990 and from the 10th August until the 9th November 1990. This represented a total of 60 days and approximately 600 hours of observation. The periphery of the study sites was checked each morning for traces of animals which may have visited them in the hours of darkness. Additional observations were carried out within the forest on three groups of babirusa. Videotape recordings were started when one or more babirusa was seen to enter the study site and continued for the duration of the time that it/they were in view. A total of $8 \mathrm{~h} 37 \mathrm{~min}$ of tape containing images of babirusa were obtained in this manner.

The age of each animal was classified according to the following scheme which was based upon personal observations and the accumulated knowledge of staff responsible for babirusa care in zoological collections; adult males were designated as animals with maxillary canines which had pierced the skin and had formed a semicircular curve of tooth through which daylight could be clearly seen (Figure 3). Subadult males were animals which showed short maxillary canine teeth that either formed a very tight semicircular curve through which very little or no daylight could be seen, or had just protruded through the skin, or showed no teeth through the skin but the developed boney alveolus under the skin of the nose. Juvenile males were smaller animals without sign of growth of the 
maxillary canines or their alveoli. Adult females were identified from subadult females by means of their size.

[fig 3 near here]

The animals were identified according to sex, age class, group size, and where possible, individuals identified. This was relatively easy to undertake in the case of males because of the shape of their canines. Some individual males were seen to visit the 'salt-licks' more than once. However, babirusa teeth are susceptible to breakage and over the time span of the study the same male may have had a changed appearance. It was impossible to identify females one from another. Additionally, in a number of instances the animals were recorded on tape for a very short time, and their sex or identity may not have been clear if the angle of view was inappropriate. For these reasons the results were not adjusted for recurring visits.

The behaviour expressed by the babirusa was classified into agonistic, 'ploughing', reproductive, and mother-infant behaviours. The agonistic behaviours were further categorised with reference to the classification, 'threat at a distance', 'nose in the air', 'head under jaw submission' and 'front half supported' used to describe the agonistic behaviour of babirusa in zoos (Macdonald et al. 1993). The 'ploughing' behaviour has likewise been described in detail from zoo-based studies by Leus et al. (1995).

\section{Results}

Group structure 
The total number of babirusa sightings recorded on videotape was 586. These comprised 161 of adult males, 155 of adult females and 11 of adults of unknown sex; there were 78 of subadult males, 53 of subadult females and a further 34 cases where it was not possible to determine the sex of the subadult animal; juveniles were observed 94 times of which 19 could be identified as males and 12 as females, the sex of the other 63 remaining unclear. The babirusa were present in groups which ranged in size from one to eight animals, with 160 groups observed at the 'Marisa' site and 66 groups at the 'Lantolo' site (Table 1). The median group size (including solitary animals) was two babirusa for both 'Marisa' and 'Lantolo'. There was no difference between the two sites in the frequency with which each group size was seen $\left(\chi^{2}=2.964, \mathrm{df}=7, \mathrm{p}>0.8\right)$. There was also no significant difference in the proportions of male, female, subadult or juvenile animals observed at the two sites. The observations made at each site have therefore been combined and the percentage of times that each group size was seen calculated (Table 1). Almost half the sightings were of single animals, whereas groups of five or more animals represented less than $20 \%$ of the groups recorded. No groups larger than eight animals were observed; when two groups were present at the 'salt-lick' at any one time they moved about the open area as separate entities. The animals filmed in the forest were excluded from the analyses because the group size and composition could not be determined with certainty.

[table 1 near here]

Most sightings of solitary animals were of adult males (Figure 3) (84\% of all solitary animals), with pairs or trio's of males rarely seen (Table 2). Single adult males were seen with single adult females, but never with two or more females unless young animals were present. Bachelor groups of four or more adult babirusa were never seen. Very few adult males (6) were seen together with young animals without adult females also being in the group (28). Adult females were rarely seen without 
company, sometimes together with other adult animals, but most often with young babirusa (Figures 4 $\& 5$; Table 2). Groups containing adult females and young numbered 84, of which two thirds (56) had no adult males present (Table 2).

[figures $4 \& 5, \&$ table 2 near here]

Single adult females with young and no adult male (38 sightings) comprised the second most frequently observed grouping of babirusa; the group size ranged from two to six animals (Tables $2 \&$ 3). The largest number of 'female' groups (17) contained one adult female and two young (Table 3). There were never more than three adult females in a group. No group had more than five young. On 12 occasions adult female(s) were seen with juveniles alone. There were 20 sightings of the adult female(s) with subadult animals only. On another 24 occasions both juveniles and subadults were sighted together with the adult female(s).

[tables $3 \& 4$ near here]

No group of adult females and young were seen with more than two adult males present (Tables $2 \&$ 4). There were about twice as many family groups without adult males (56) as there were with males (28). Of those there were 21 with one adult male and only 7 with two adult males (Tables $2 \& 3$ ). In 18 out of 28 cases where one or two adult males were present in the family group, juvenile animals were also present (Table 4). 
There were twelve groups of animals which demonstrated some form of identifiable agonistic behaviour on video. Usually these interactions were between male animals in which one male glanced over at another ('threat at a distance') and the other lowered his head, or animals when approaching one another would lift their heads and put their noses in the air ('nose in the air'), or one male would place his ears tight back against his head which he then lowered below the mandible of the other, often older adult male whose head was held higher and whose ears are held upright ('head under jaw submission'). The lower, submissive male would sometimes utter a long rattling screech. There was no sound recorded from the dominant male.

On four occasions the behaviour known as 'front half supported' was observed. In one of these, because of partial forest obstruction, it was not clear whether it was like the second occasion, which was partly play behaviour between younger animals. Of the other two incidents the following is illustrative of the behaviour. An old male babirusa (A) walked in the direction of two other males on the 'salt-lick', but was temporarily diverted from them by the presence of a female. She placed her snout under his mandible. He continued walking in the direction of the other males. Male (B), with his head held high and his ears pointed forward walked towards male (A). The old male (A) lowered his head in response. Male (B) then diverted his attention to the other older male (C) which did not have his head lower. Male (B) climbed with his forelimbs onto the head and shoulder of male (C) who screamed throughout this procedure. The scream went down in pitch and intensity during the confrontation. Male (B) ended the confrontation by dismounting. He then walked in the direction of male (A) with his ears held forward. Meanwhile, male (C) kept his head down and moved the rear of his body round so that his lowered head always pointed towards male (B). The latter approached male (A) which by now had also raised his head. The approach of male (B) was made side-ways on with the left shoulder leading, head and ears raised. Male (A) has lowered his head mean while male 
(B) put his weight onto his back legs and climbed onto the head and shoulders of male (A). Male (A) lifted one foreleg off the ground but never got both forelimbs into the air. Male (A) screamed as male (B) dismounted with his head raised. Male (A) again faced his attacker with lowered head and started to retreat. As he was retreating, male (C) was approaching him with its ears forward. Male (A) spun around to face the new potential danger. He then lowered his head to male $(\mathrm{C})$ and the two did not fight. Male (B) walked off the site.

Two female-female interactions were observed. In one, the female (A) closest to the camera lowered her head and the other female (B) reached high. Female (A) lunged forward with her head down. Both females then attempted to go onto their hind legs with heads raised. Female (A) was pushed over by female (B). Female (A) then immediately lunged back for the feet of female (B) on two occasions one quickly followed by the other. The animals ended up side by side, with their heads pointing in opposite directions. The head of female (A) was thumped into the thorax and abdomen of female (B). Female (B) was thrown a short distance. Female (A) immediately thumped her again on the same part of the body, this time with even more force, and female (B) was thrown at least two meters away. Female (B) then rapidly ran towards the forest, pursued for a distance of 5-6m by female (A). Two juvenile babirusa which were present during the fight showed no signs of anxiety, and only moved out of the way if there was a suggestion that the fight was coming towards them. After female (B) had left the scene, one of the juveniles came to nose the snout of female (A), and then ran off after female (B). A deep throated growling was recorded during the fight and a short 'woh' sound was heard at the end. It was not clear which animals were vocalising. In an encounter between two other female babirusa, the departing female uttered a long scream as she was chased.

\section{'Ploughing' behaviour}


This behaviour was observed at the 'salt-lick' on six occasions, three times by adult males, once by a subadult male and twice by juvenile animals. In the clearest example, an adult male stood in the mud which he lifted with his nose for a few seconds. He then pushed the mud forward with his nose, knelt down and using his hind limbs for propulsion, slid forward onto his chest with his nose in the mud for a couple of seconds. He then rolled to the right and to the left on his belly with his feet under him. After rolling to the left once more he lay straight for a short while before getting to his feet.

\section{Reproductive behaviour}

Three short periods of reproductive behaviour were observed. In each an adult male was seen following an adult female and appeared to be sniffing and mouthing her perineal region. In one this behaviour was interrupted by the arrival of a juvenile animal.

\section{Mother-piglet behaviour}

There were three sequences of video film with singleton infants suckling, and one sequence with twins suckling. In the former the young piglets appeared to be obtaining milk for a long period of time despite their mothers moving about the 'salt-lick'. Despite this movement repeatedly breaking the physical contact between sow and piglets, the youngsters also sometimes managed to retain the teat in their mouths and continued suckling as the sow moved. This maintenance of contact was most often seen when piglets suckled from behind the mother, alternating between the two hind teats. One piglet seemed to obtain milk from both fore and hind teats by moving in front of or behind the hind limb of its mother. However, in this very small sample, the hind teats appeared to be suckled most often. The piglet occasionally nudged its nose lightly into the udder (a gentle fluent movement rather than a banging movement), used tongue movements with the teat, and occasionally pulled on the teat. 
It is interesting to note that there was a single sequence where two similarly sized piglets approached the udder of a sow at the same time, and the animal that had been suckling chased the other piglet away. In the sequence where twin piglets were suckling, one approached the udder from the rear of the standing sow, and the other from her left side. The piglet from the rear suckled the right hind teat and the one from the left suckled both of the fore teats.

\section{Discussion}

This study represents the first description of group structure in a large population of babirusa in the wild. The largest proportion of sightings of babirusa was of a solitary animal, a finding that is comparable to observations made on other species of pig (Table 5). Groups of two to five animals were also relatively frequently observed in other pig species; approximately the same range of group sizes seems to apply to the pigmy hog (Sus salvanius) and the Javan warty pig (Sus verrucosus) although no detailed studies have yet been carried out on these threatened pig species (Oliver 1980; Oliver and Deb Roy 1993; Blouch 1988, 1993). The main difference the babirusa shows with respect to the other pig species is in the maximum group size observed (Table 5). Groups of the Eurasian wild pig (Sus scrofa) in the Camargue, France, occasionally reached sizes of 23 animals (Dardaillon 1988), and about $9 \%$ of all observations made during a study in Germany were represented by groups of more than 20 individuals (Briedermann 1990). Common warthog (Phacochoerus africanus) groups can occasionally contain up to 16 individuals (Cumming 1975). Two other pig species appear to travel in much bigger groups. The only detailed field study carried out on the red river hog (Potamochoerus porcus) reported an average group size of 10.56 animals (Oduro 1989 reported by Vercammen et al. 1993). The sundaic bearded pig (Sus barbatus barbatus) of Borneo is well known to aggregate in groups of hundreds of individuals that migrate together (Caldecott 1991a,b). There 
are no published records of such large gatherings of babirusa, the largest group size recorded during the present study being of eight individuals.

[table 5 near here]

Pig group size can be influenced by climatic conditions, food availability, hunting and deforestation pressure, the timing of the reproductive cycle, and the numbers of young born, predation etc. (Cumming 1975; d'Huart 1978; Dardaillon 1988; Briedermann 1990; Caldecott 1991a,b). It is important to bear in mind, therefore, that most of the recordings of babirusa were made during August-November, towards the end of the 'dry' season. The abundance of larger groups of common warthog is said to increase during the rainy season (Cumming 1975). We do not have comparable year-round information on babirusa group size from north Sulawesi to be able to carry out this type of analysis.

The information available on the digestion of food by the babirusa suggests that fruits may be an important component of the diet (Leus 1994). Unfortunately, there is no information available on the fruiting pattern of the trees in the forests of the Minahasa peninsula, nor on the precise nature of the diet in the wild. The bearded pig demonstrates the most dramatic relationship between large increases in group size and the increases in the availability of fruit within the forests of Borneo (Caldecott 1991a,b). Other studies, of the diet in the wild and the fruiting patterns of the forest are also required to help explain how diet availability may influence group size, structure and home range.

Recent reports presented not only evidence of deforestation, but also of hunting and mining pressure in the broad valley where the video filming of babirusa took place (Florence 1995; Collet 1995). 
Studies of the Eurasian wild pig in Europe have indicated that larger associations of animals will split up into smaller groups as hunting pressure increases (Briedermann 1990). Whether group fragmentation of the babirusa has taken place in a similar way is unclear. Our results suggest that further studies of babirusa in less disturbed areas of Sulawesi may be necessary in order to reveal whether their group size is larger as the amount of disturbance is reduced.

There is no information from the wild relating the time of birth of babirusa to climatic change. Studies in zoological collections demonstrate that babirusa have oestrus cycle lengths of between 28 and 42 days and are able to breed all the year round (Macdonald 1993; Plasa 1994). Gestation length is usually 155-158 days, though up to 171 days has been reported (Reinhard and Frädrich 1983; Macdonald 1993). The normal litter size is one or two, though a low incidence of triplet births has been recorded both in captivity and in the wild, and four fetuses have been reported in utero in a wild female (Patry 1990). The present study indicated the presence of singletons and twins, but there was no clear evidence of triplets (Table 3). The small size of the litter, therefore contributes directly to the small size of the groups of babirusa when compared to groups of Sus species. The close bonding between female babirusa and her young, seen in zoological collections, seemed to be reflected in the sow plus two litter structure of a number of the family groups reported in the present study (Table 3 and Figure 5). The precise role played by young from the previous litter is not clear.

Although the open nature of the study sites and the fact that the proceedings were videotaped permitted detailed analyses of the composition of the groups, care must be exercised in the interpretation of observations made on animals in the open at a 'salt-lick' during daytime. Likewise, care must be taken in the extrapolation of behaviour so observed to the type of behaviour which the same animals may express within the forest and at night. The few glimpses of male babirusa in the 
forest lent support to the notion that they are mainly solitary. Our only observations of night-time behaviour of animals in the wild was that babirusa did not come to the 'salt-lick' after dark. Studies in zoos suggest that in the late afternoon and at night-fall they may sleep together in groups (Macdonald et al. 1989; Leus et al. 1992; Macdonald 1993). The gathering of groups of red river hog to sleep together has been observed in West Africa (Ben Voysey personal communication). Babirusa nests on the Togian islands, however, have been described as single-animal sized structures (Selmier 1978, 1983). Further studies in the forest are required to resolve these apparent contradictions.

During the present study solitary adult males (Figure 3) were observed most frequently (38.5\%). The only times that adult male Eurasian wild pig associate with matriarchal groups were when the females were in oestrus; at other times they were solitary (Dardaillon 1988; Briedermann 1990). Adult male common warthog either live alone or in bachelor groups and are found with females almost exclusively during the mating season (Cumming 1975; Mason 1982; Vercammen and Mason 1993). Adult male bushpigs (Potamochoerus larvatus) associate with the female and her offspring for a much longer time, the association often continuing even after the young are weaned (Seydack 1991). This type of relationship seems to be taken a step further by adult male forest hogs (Hylochoerus meinertzhageni) which live with the family group at all times, and usually become solitary only after they have been expelled from the group by another male (d'Huart 1978, 1991). In case of the babirusa, matriarchal groups seemed to occur more frequently, and family groups (groups including one or more adult males) less frequently than was the case for the bushpig and the forest hog (d'Huart 1978, 1991; Seydack 1990, 1991). The babirusa exhibited almost no reproductive behaviour on the 'salt-lick' throughout the period of the present study. Seasonal differences in the degree of association between adult male and female babirusa remain to be studied. 
Observation of the babirusa in zoological collections has revealed a series of behaviours which male animals appear to use in order to establish rank with respect to other males (Macdonald et al. 1993). The increasing levels of threat behaviour, 'threat at a distance', 'nose in the air' and 'front half supported' which were described from the agonistic behaviour of groups of captive male babirusa, were all observed at the 'salt-lick' in the course of the present study. Subadult and smaller males appeared to defer to larger adult males. However, as in the zoos, where the animals were more evenly matched for size, the dominant animal seemed to posses other characteristics (willingness to promote the threat, perhaps) from which he derived that status. The details of each behaviour were indistinguishable from those observed under captive conditions. Only about $5 \%$ of the interactions between zoo males resulted in the next level of threat, 'boxing' behaviour. This behaviour is often a progression from 'front half supported' in which both animals raise their front legs off the ground, and while standing on their hind legs facing one another, paddle for some minutes against the chest and shoulders of their opponent. The reason we did not observe this behaviour may be due to differences in the relative benefits individuals derived from sampling the 'salt-lick', as opposed to exerting dominance. Not infrequently the sounds of strenuous agonistic behaviour were heard near the 'salt-lick' but out of sight in the forest, but it was never clear which species of pig, Babyrousa babyrussa, or the more common Sulawesi Warty pig (Sus celebensis) was responsible for this. The relative infrequency with which males demonstrated 'ploughing behaviour' on the 'salt-lick' may similarly be related to some, currently unclear, lack of need to mark this piece of land. 'Ploughing behaviour' in zoological collections has been associated with the deposition of pheromones on the soil by mature males when introduced to a fresh enclosure, or to one previously occupied by another adult male (Leus et al. 1995). Other unpublished studies suggest that this marking behaviour may take place elsewhere in the forest. 
The majority of groups with females tended to have a single adult female with young, although more than one female babirusa with young may be found together (Figure 4). This relative preponderance of single females with young may be an adaptation to safeguard against opportunistic cannibalism by adult babirusa of the new-born young of other babirusa, which has been observed in zoological gardens (Bowles 1986; Macdonald et al. 1989; Leus et al. 1992). These observations on group structure may be related to the attacks we observed being made by one female on another. It was not clear if either of the combatants was pregnant. Immediately prior to parturition the babirusa sow tends to be much more aggressive (Leus et al. 1992).

In conclusion, babirusa in North Sulawesi were diurnal in their use of the 'salt-licks'. They travelled in small groups, the adult males tending to be solitary whereas the adult females tended to be accompanied by young animals of one or two generations. Large bachelor groups were not seen. Groups rarely contained three or more adult females. The range of agonistic and ploughing behaviours observed were indistinguishable from those exhibited by babirusa in zoological collections.

\section{Acknowledgements}

We are grateful to the Development Trust of the University of Edinburgh, the Commission of the European Community and the Balloch Trust for their financial support, to Susan Wexler for graphics assistance and to Jacques Poulard, Colin Warwick and Pyramid for their photographic expertise. Many thanks also to Docteur Sander Batuna, Ilyanto and Paul Vercammen for their assistance.

\section{Bibliography}


Audley-Charles, M.G. 1981. Geological history of the region of Wallace's Line. In: Whitmore, T.C. (ed.) Wallace's line and plate tectonics. Clarendon Press: Oxford. 24-35.

Blouch, R.A. 1988. Ecology and conservation of the Javan Warty Pig Sus verrucosus Müller, 1840. Biological Conservation 43, 295-307.

Blouch, R.A. 1989. Report from the field: Indonesia. Smithsonian Institute Conservation and Research Center Newsletter, National Zoo, Washington D.C., 1, 6-8.

Blouch, R.A. 1993. The Javan Warty Pig (Sus verrucosus). In: Oliver, W.L.R. (ed.) Status survey and conservation action plan: Pigs, Peccaries and Hippos. IUCN: Gland, Switzerland. 129-136.

Bosma, A.A.; de Haan, N.A. and Macdonald, A.A. 1991. The current status of cytogenetics of the Suidae: a review. Bongo, Berlin 18, 260-272.

Bowles, D. 1986. Social behaviour and breeding of babirusa Babyrousa babyrussa at the Jersey Wildlife Preservation Trust. Dodo 23, 86-94.

Briedermann, L. 1990. Schwarzwild. VEB Deutscher Landwirtschaftsverlag: Berlin. 540pp.

Caldecott, J. 1991a. Monographie des Bartschweines (Sus barbatus). Bongo, Berlin 18, 54-68.

Caldecott, J. 1991b. Eruptions and migrations of bearded pig populations. Bongo, Berlin 18, 233-243. 
Collet, J-Y, !995. Foux d'animaux: les aventures de Papiroussa. Léo productions (film): Boulogne, France.

Cumming, D.H.M. 1975. A field study of the ecology and behaviour of warthog. Museum Memoir 7, Salisbury, Rhodesia. 179pp.

Dardaillon, M. 1988. Wild boar social groupings and their seasonal changes in the Camargue, southern France. Zeitschrift für Säugetierkunde 53, 22-30.

D'Huart, J.P. 1978. Écologie de l'Hylochère (Hylochoerus meinertzhageni Thomas) au Parc National des Virunga. Fondations pour favoriser les recherches scientifiques en Afrique, 2e Série, fascilule 25, 156pp.

D'Huart, J.P. 1991. Monographie des Riesenwaldschweines (Hylochoerus meinertzhageni). Bongo, Berlin 18, 103-118.

Florence, A. 1995. Sulawesi: an island bewitched. BBC 'Natural World' film: BBC, Bristol.

Guillemard, F.H.H. 1886. The cruise of the Marchesa to Kamschatka and New Guinea. J. Murray: London. 2, 190-191, 200-205.

Leus, K. 1993. La grande expedition des babiroussas dans la "presque-jungle" de St-Martin. Magazine Trimestriel. Espace Zoologique. St Martin la Plaine. 30, 4. 
Leus, K. 1994. Foraging behaviour, food selection and diet digestion of Babyrousa babyrussa (Suidae, Mammalia). Thesis presented for the degree of Doctor of Philosophy. The University of $\quad$ Edinburgh. 302pp.

Leus, K.; Bowles, D.; Bell, J. and Macdonald, A.A. 1992. Behaviour of the babirusa (Babyrousa babyrussa) with suggestions for husbandry. Acta Zoologica et Pathologica Antverpiensia 82, $1-19$.

Leus, K., Bland, K.P., Dhondt, A.A. and Macdonald, A.A. 1995. Ploughing behaviour of the babirusa (Babyrousa babyrussa) suggests a scent marking function. Journal of Zoology (in press).

Macdonald, A.A. 1993. The babirusa (Babyrousa babyrussa). In: Oliver, W.L.R. (ed.) Status survey and conservation action plan: Pigs, Peccaries and Hippos. IUCN: Gland, Switzerland. 161171.

Macdonald, A.A.; Bell, J.; Munro, S.A.; Kaspe, L.; Harwono Gepak, V.; Sasmita, R. and Bowles, D. 1989. Observations on the behaviour and health of captive babirusa. In "Prociding Simposium Nasional Penyakit Satwa Liar". Universitas Airlangga dan Kebun Binatang: Surabaya, Indonesia. 244-253.

Macdonald, A.A.; Bowles, D.; Bell, J. and Leus, K. 1993. Agonistic behaviour in captive babirusa (Babyrousa babyrussa). Zeitschrift für Säugetierkunde 58, 18-30. 
Mason, D.R. 1982. Studies on the biology and ecology of the warthog Phacochoerus aethiopicus sundevalli Lönnberg, 1908 in Zululand. Dissertation for the degree of D.Sc. (Wildlife Mangement), University of Pretoria, Pretoria. 335pp.

Oduro, W. 1989. Ecology of the red river hog in Southern Nigeria. PhD thesis, Univ of Ibadan, Nigeria.

Oliver, W.L.R. 1980. The pigmy hog. The Jersey Wildlife Preservation Trust Special Scientific Report No. 1. The Jersey Wildlife Preservation Trust: Trinity, Jersey.

Oliver, W.L.R. (ed.) 1993. Status survey and conservation action plan: Pigs, Peccaries and Hippos. IUCN: Gland, Switzerland. 202pp.

Oliver, W.L.R. and Deb Roy, S. 1993. The Pygmy Hog (Sus salvanius). In: Oliver, W.L.R. (ed.) Status survey and conservation action plan: Pigs, Peccaries and Hippos. IUCN: Gland, Switzerland. 121-129.

Plasa, L. 1994. Internationales Zuchtbuch für den Hirscheber (International studbook for the babirusa) Babyrousa babyrussa 1993. Wilhelma Zoologisch-botanischer Garten: Stuttgart, 21pp.

Patry, M. 1990. Babiroussa, une vie jusqu'au bout du rêve. Paris: Fixot. 221pp.

Poulard, J. and Patry, M. 1990. Geheimnisvolle Hirsch-Eber. Das Tier. Januari 1990, 70-75. 
Reinhard, R. and Frädrich, H. 1983. Bemerkung zur Zucht Hirschebern (Babyrousa babyrussa L.) im Zoo Berlin. Bongo, Berlin 7, 65-70.

Römer, A.S. 1966. Vertebrate Paleontology. 3rd Ed. Chicago University Press: Chicago.

Selmier, V.J. 1978. Only in Indonesia: the babirusa. Unpublished report to LIPI and PPA: Jakarta.

Selmier, V.J. 1983. Bestandsgröße und Verhalten des Hirschebers Babyrousa babyrussa auf den Togian-Inseln. Bongo, Berlin 7, 51-64.

Seydack, A.H.W. 1990. Ecology of the bushpig Potamochoerus porcus Linn. 1758 in the Cape Province, South Africa. PhD thesis. Univeristy of Stellenbosch. 728pp.

Seydack, A. 1991. Monographie des Buschschweines (Potamochoerus porcus). Bongo, Berlin 18, 85102.

Smiet, F. 1982. Threats to the spice islands. Oryx 14, 323-328.

Stresemann, E. 1925. Begegnungen mit dem Hirscheber (Babirussa babyrussa) auf Buru. Pallasia 3, 49-56.

Valentijn, F. 1726. Oud en Nieuw Oost-Indien. J. van Braam: Dordrecht, Amsterdam. 5, 268-269. 
Vercammen, P. and Mason, D.R. 1993. The Warthogs (Phacochoerus africanus and P. aethiopicus). In: Oliver, W.L.R. (ed.) Status survey and conservation action plan: Pigs, Peccaries and Hippos. IUCN: Gland, Switzerland. 75-84.

Vercammen, P.; Seydack, A.H.W. and Oliver, W.L.R. (1993). The Bush Pigs (Potamochoerus larvatus and P. porcus). In: Oliver, W.L.R. (ed.) Status survey and conservation action plan: Pigs, Peccaries and Hippos. IUCN: Gland, Switzerland. 93-101.

Whitten, A.J.; Mustafa, M. and Henderson, G.S. 1987. The ecology of Sulawesi. Gadjah Mada University Press: Yogyakarta, Indonesia. 777pp. 


\section{Figure Legends}

Figure 1: $\quad$ The group of Indonesian islands upon which babirusa are found. The region of the study sites is indicated by the shaded area on the Minahasa peninsula of Sulawesi.

Figure 2: $\quad$ Schematic diagrams to illustrate the layout of the 'Malisa' and 'Lantolo' study sites with the positions of the observation hides $(1,2,3,4)$ and the prominent 'tree', 'spring' and fallen 'tree trunk' landmarks indicated. The sites were situated approximately $15 \mathrm{~km}$ apart.

Figure 3: $\quad$ A solitary adult male babirusa beside the tree at the 'Marisa' study site. There was a water source between the tree's roots where many babirusa came to drink.

Figure 4: A group of four babirusa, comprising two adult females and two juveniles, by the edge of the forest near the spring at the 'Marisa' study site..

Figure 5: $\quad$ A group of eight babirusa, comprising adult, subadult and juvenile animals, sampling the 'salt-lick' just in front of the shadow cast by the large fallen tree trunk at the 'Lantolo' study site. 
Table 1 The numbers of groups of babirusa of different size recorded at the 'Marisa' and 'Lantolo'study sites and the percentage of the total represented by each group size.

\begin{tabular}{|c|c|c|c|c|}
\hline Group size & 'Marisa' & 'Lantolo' & Total & Total (\%) \\
\hline 1 & 74 & 30 & 104 & 46.0 \\
\hline 2 & 21 & 6 & 27 & 11.9 \\
\hline 3 & 26 & 9 & 35 & 15.5 \\
\hline 4 & 14 & 6 & 20 & 8.8 \\
\hline 5 & 10 & 5 & 15 & 6.6 \\
\hline 6 & 8 & 4 & 12 & 5.3 \\
\hline 7 & 4 & 3 & 7 & 3.1 \\
\hline 8 & 3 & 3 & 6 & 2.7 \\
\hline Totals & 160 & 66 & 226 & 100 \\
\hline
\end{tabular}


Table 2 Numbers of groups of babirusa arranged according to the number of adult males and females present and according to the presence or absence of youngsters (groups containing adults of unknown sex were not included).

\section{Adult males}

0

1

2

3

Adult females

0 female only

87

2

0 female + young

6

0

Total

93

2

1 female only

6

1 female + young

38

44

2 females only

3

0

0

2 females + young

13

7

0

Total

16

7

0

3 females only

1

0

0

3 females + young

5

6

2

1

Total

6

2

1

4 females only

0

0

4 females + young

0

1

Total

0 
Table 3. The number of groups with young of both sexes seen together with adult female, but not adult male, babirusa. The young animals are subdivided into subadult and juvenile classes.

\section{Adult females}

Young animals

1 Subadult

1 Juvenile

2 Subadults

1 Subadult +1 Juvenile

2 Juveniles

3 Subadults

1 Subadult +2 Juveniles

2 Subadults +1 Juvenile

4 Subadults

3 Subadults +1 Juvenile

2 Subadults +2 Juveniles

3 Subadults +2 Juveniles

2 Subadults +3 Juveniles

1 Subadult +4 Juveniles
1

5

4 5

10

2

3

1

3

0

3

1

1

0

0
2

3

0

0

1

2

0

0

0

$4 \quad 1$

1

1

0

0

$0 \quad 0$

$\begin{array}{ll}0 & 1 \\ 0 & 0 \\ 3 & 0\end{array}$

$\begin{array}{ll}0 & 0 \\ 0 & 1\end{array}$

0

1 
Table 4. The number of groups with young of both sexes seen together with adult female and male babirusa. The young animals are subdivided into subadult and juvenile classes.

\section{Adult females}

\section{One adult male +}

1 subadult

1 juvenile

1

3

0

0

0

2 subadults

2

0

0

1 subadult +1 juvenile

0

2

0

2 juveniles

1

0

0

3 subadults

2 subadults +1 juvenile

0

2

1 subadult +2 juveniles

3 juveniles

0

4 subadults

1 subadult +3 juvenile

3 subadult +1 juvenile

\section{0}

1

0

4 subadult +1 juvenile

0

0

0

1

0

0

1

0

0

0

0

\section{Two adult males +}

1 subadult

1

0

0

2 subadults

1 subadult +1 juvenile

1

0

1

0

3 juvenile

0

1

0

3 subadult +1 juvenile

0

1

0

1


Table 5. Relative abundance (\%) of different group sizes in four species of wild pig.

\begin{tabular}{|c|c|c|c|c|}
\hline Sample size & $\begin{array}{l}\text { Babyrousa } \\
\text { babyrussa } \\
(\mathrm{n}=226)\end{array}$ & $\begin{array}{l}\text { Potamochoerus } \\
\qquad \text { larvatus }^{1} \\
(\mathrm{n}=153)\end{array}$ & $\begin{array}{c}\text { Sus } \\
\text { scrofa }{ }^{2} \\
(\mathrm{n}=872)\end{array}$ & $\begin{array}{l}\text { Phacochoerus } \\
\text { africanus }^{3} \\
(\mathrm{n}=1332)\end{array}$ \\
\hline Relative abundance & $(\%)$ & $(\%)$ & $(\%)$ & $(\%)$ \\
\hline \multicolumn{5}{|l|}{ Group size } \\
\hline 1 & 46.0 & 33.3 & 34.3 & 20.0 \\
\hline 2 & 11.9 & 28.8 & 11.7 & 19.0 \\
\hline 3 & 15.5 & 16.3 & 10.6 & 15.3 \\
\hline 4 & 8.8 & 13.1 & 8.7 & 11.7 \\
\hline 5 & 6.6 & 3.9 & 8.7 & 12.7 \\
\hline 6 & 5.3 & 2.0 & 5.5 & 9.0 \\
\hline 7 & 3.1 & 1.3 & 4.6 & 7.0 \\
\hline 8 & 2.7 & 0 & 3.6 & 2.3 \\
\hline 9 & 0 & 0.7 & 3.3 & 2.3 \\
\hline 10 & 0 & 0.7 & 2.2 & 0.7 \\
\hline $11-15$ & 0 & 0 & 4.9 & 1.4 \\
\hline $16-20$ & 0 & 0 & 1.4 & 0.2 \\
\hline$>20$ & 0 & 0 & 0.1 & 0 \\
\hline
\end{tabular}

${ }^{1}$ Seydack (1990); ${ }^{2}$ Dardaillon (1988); ${ }^{3}$ Cumming (1975) 
(1)

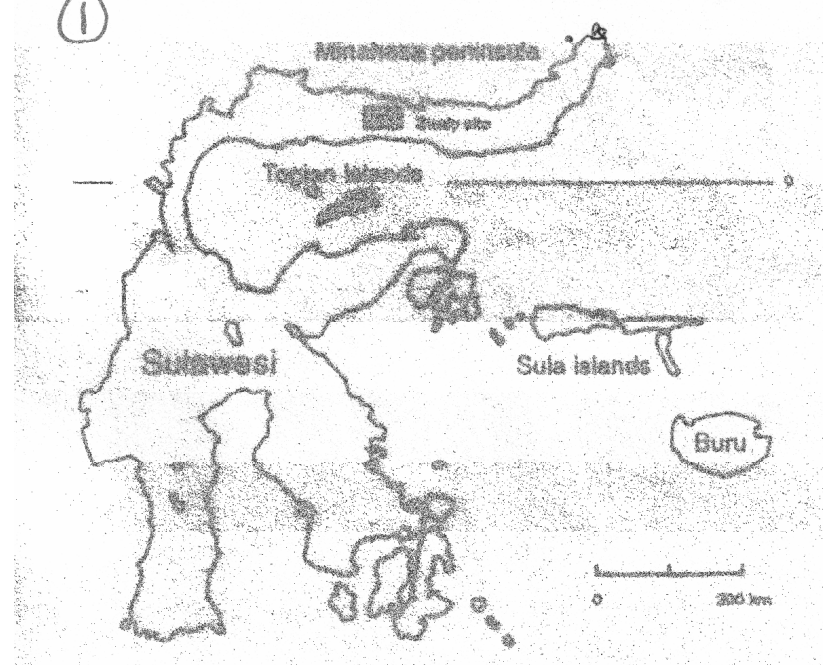

(2)

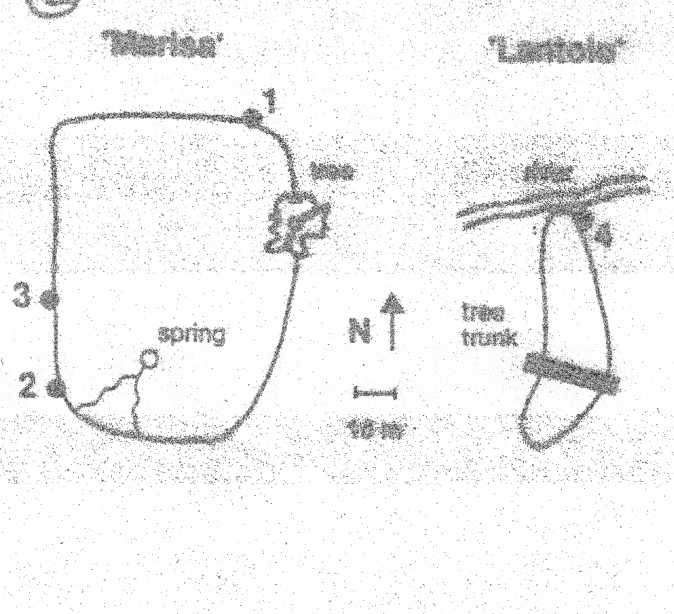

(3)

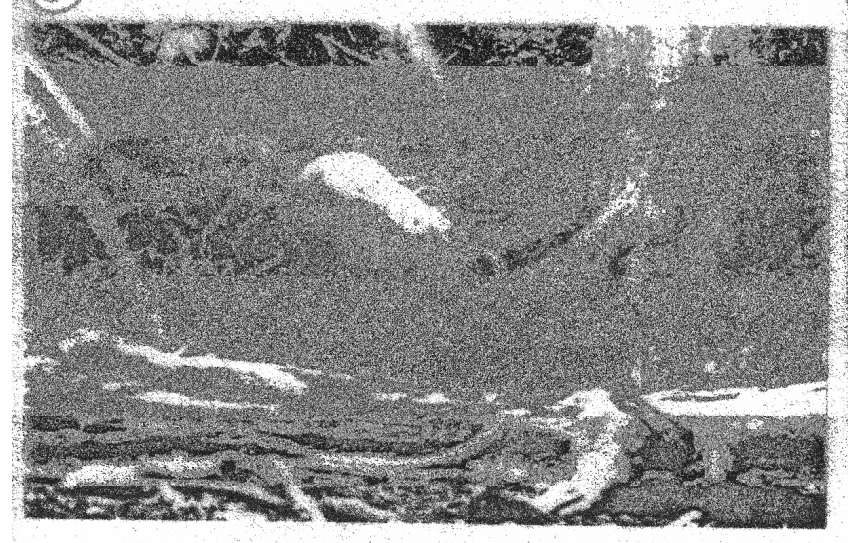

(4)

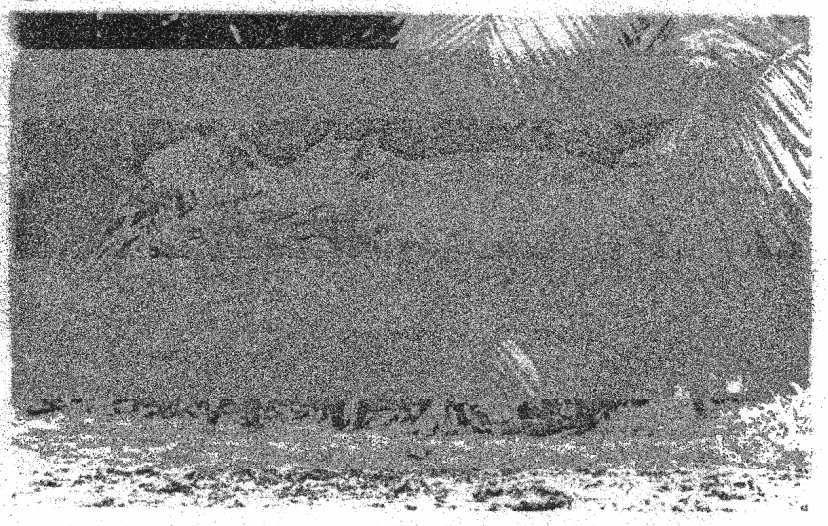

(5)

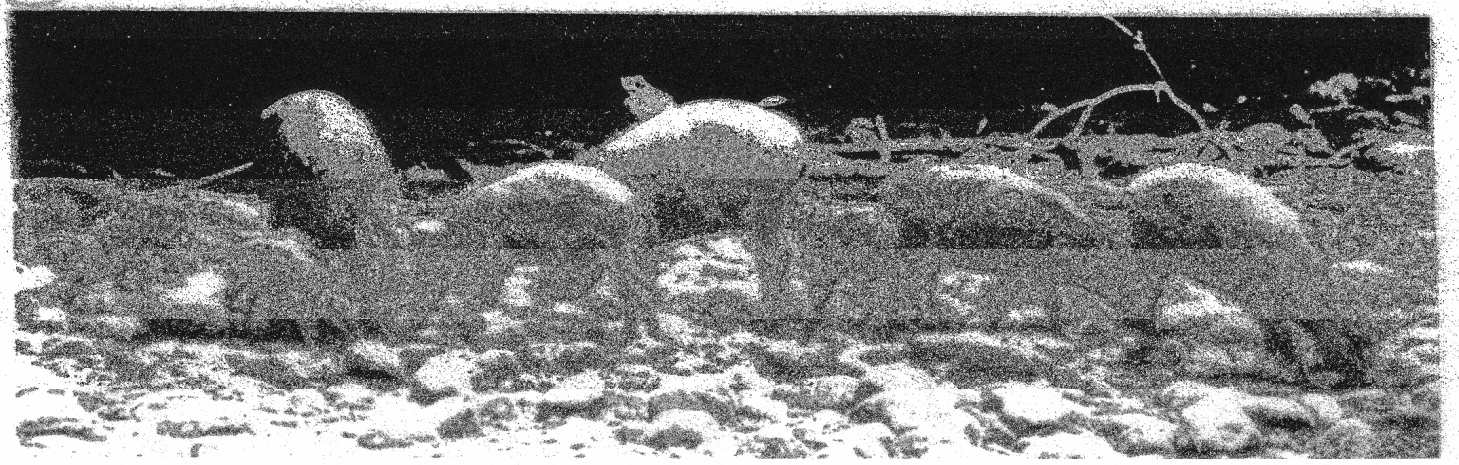

